Running head: THREATENING OTHERS

"Threatening Others":

National Identity and Group Threats Predict Immigration Policy

Ludwin E. Molina

Justin Preddie

University of Kansas

Word Count: 8,114

Address correspondence to:

Ludwin E. Molina

University of Kansas

1415 Jayhawk Blvd., Room 426

Lawrence, KS 66045

USA

Author Note: This research was funded by a University of Kansas General Research Fund (GRF) grant to the first author: 


\begin{abstract}
The present research examines the relationship between national identity, perceived group threats, and immigration policy. Across two studies, we examine how patriotism (an arguably critical form of national identity) and nationalism (an ethnocentric and dominance-oriented form of national identity; Sidanius, Feshbach, Levin, \& Pratto, 1997) predict strong stances on immigration policy (Studies $1 \& 2$ ). Furthermore, does the inclusion of symbolic threats (Studies $1 \& 2$ ) and realistic threats (Study 2) attenuate the relationship between different forms of national identity and immigration policy? One of the key findings across the two studies is that the inclusion of symbolic threats attenuate the positive relationship between nationalism and immigration policy but not the relationship between patriotism and immigration policy. The present findings extend previous research (Mukherjee et al., 2012) by providing evidence that symbolic threats (e.g., immigrants are changing what it means to be American) underpin the relationship between nationalism and immigration policy.
\end{abstract}

Keywords: Immigration, nation, race, diversity, symbolic threat, realistic threat 


\section{"Threatening Others":}

National Identity and Group Threats Predict Immigration Policy

National identity and immigration are inextricably linked. A recent example is how the issue of immigration played a key role in the 2016 U.S. Presidential Election. Political rhetoric of "Build a Wall" and a "Muslim Ban" garnered traction across a broad swath of the U.S. populace to elect a President that is trying to make good on his campaign promises. The past several years in the U.S. have been defined politically by issues of nation, group threats, and immigration. The present paper focuses on these three constructs to examine how different forms of national identity and group threats (e.g., realistic and symbolic) predict stances on immigration policy. In particular, patriotism, an arguably critical form of national identity, and nationalism, an ethnocentric and dominance-oriented form of national identity, (Sidanius, Feshbach, Levin, \& Pratto, 1997) are employed to predict attitudes toward immigration policy. In addition, perceived symbolic and realitic threats are included to examine whether they attenuate the relationship between national identity and immigration policy. The present research extends previous work (see Mukherjee, Molina, \& Adams, 2012) by providing evidence that symbolic threats (e.g., immigrants are changing what it means to be American) underpin the relationship between nationalism and immigration policy but not patriotism and immigration policy. A second contribution is that we examine the contours of these relationships across an array of immigration policy that emphasize: cultural assimilation (e.g., bilingual education), restrictiveness (e.g., deportation and building a wall on the Southern border), punitveness targeting ingroups (i.e., punishment of American employers who hire undocumented immigrants) or outgroups (i.e., punishment of undocumented immigrants). 
The present research proposes that tough stances on immigration are driven in part by identity-concerns (e.g., protecting constructions of national identity) rather than solely 'rule of law' (e.g., people who break laws must be punished) or realistic concerns (e.g., immigrants are taking away our jobs). We do not deny that 'rule of law' or 'realistic concerns' inform people's attitudes toward immigration; rather we propose that what also informs strong stances on immigration is a fear that "one's country is changing" - a symbolic threat. To the extent that individuals have a particular construction of the U.S. (e.g., America=White; Devos \& Banaji, $2005)$ this should predict strong support for certain types of immigration policy. We make this claim for identity concerns based on several lines of research which we review next.

\section{National Identity as 'Imagined Community'}

Benedict Anderson (1983) in his seminal book, "Imagined Communities" proposes that nation is imagined because members of even the smallest nations will never get to know the majority of the members. Being a member of a nation affords an individual a connection to a group of people even though one will never come into contact with the majority of the people in that community. Nation as an imagined community suggests that nation is a psychological construct with the capacity to connect people (see Brubaker, 1996).

While we agree with this notion, the present work proposes that nation as imagined community may valorize certain subgroups (White, male; Nagel, 1998) and values (independence; Markus, 2017). In other words, the ‘imagined community’ rather than being inclusive can be quite exclusive and hierarchical (Staerkle, Sidanius, Green, \& Molina, 2010). Particular constructions of national identity may privilege certain groups because those groups are the prototype of what it means to be American. 
America $=$ White. National identities are not neutral and reflect particular ways of constructing nation that typically align with the interests and values of groups with high power and status (Mummendey \& Wenzel, 1999; Reicher \& Hopkins, 2001; Sidanius \& Petrocik, 2001). Two distinct streams of research resonate with the idea that the U.S. nation is reflective of the White racial majority. In one line, Devos and Banaji (2005) employ the implicit association test (IAT) to show that U.S. symbols (e.g., the White House) are more quickly associated with faces of White individuals than Black individuals. They argue it is indicative that "America" is equal to what it means to be "White." In a second line, Sidanius and colleagues (1997) show: (1) White respondents have significantly higher levels of national identification (e.g., patriotism, nationalism) compared to ethnic/racial minorities (e.g., Blacks); and (2) White respondents have significantly more positive associations between national and racial identities compared to minorities. These differences reflect a subgroup asymmetry effect which captures a higher sense of 'ownership' of the nation by Whites compared to minorities (see Staerkle et al., 2010). Taken together, this work suggests that national identity can partition people and an 'imagined community' can afford a sense of belonging for some groups and not others.

There is substantial psychological research that approaches national identity via measurement of the construct. The present research takes this approach and operationalizes national identity as patriotism and nationalism. We focus on these specific forms of national identity because of their relevancce to immigration policy. Within U.S. political rhetoric there is much discussion of tough stances on immigration in order to "protect" the nation and its citizenry. Whether the construction of nation is defined by positive affect towards the country (e.g., patriotism) or a sense that one's country is superior to other countries (e.g., nationalism) may have bearing on how people support certain types of immigration policy. 
Patriotism \& nationalism. Kosterman and Feshbach (1989) provided the first theoretical account and evidence distinguishing patriotism and nationalism. Since their work, substantive theoretical and empirical distinction has been drawn between these two concepts despite their shared focus on attitudes and feelings regarding the nation (see Blank \& Schmidt, 2003; Mummendey, Klink, \& Brown, 2001; Sidanius, Feshbach, Levin, \& Pratto, 1997). In brief, patriotism is the warmth and pride an individual feels for their nation and its symbols (e.g., flag, national anthem; see Bar-Tal \& Staub, 1997 for an extensive review of patriotism) combined with an openness to being critical of one's nation (Schatz et al., 1999).

Alternatively, nationalism measures the degree to which the individual believes their country is superior and dominant to other nation(s) (see Kosterman and Feshbach, 1989; Sidanius et al., 1997) and emphasizes the social comparisons one makes regarding the relative standing of their nation with other nations in the world. While feelings of nationalism might coincide with feelings of patriotism it is possible that an individual might be patriotic but not be nationalistic (cf. Schatz, Staub, \& Lavine, 1999).

The present study examines how patriotism, an arguably critical form of national identity, and nationalism, an ethnocentric, glorifying, and dominance-oriented form of national identity, (Sidanius et al., 1997) predict stances on immigration policy.

\section{Stances on U.S. Immigration Policy: "Rule of Law" or "Identity-Driven"?}

Tough stances on immigration have usually been understood to emanate from concerns with either "rule of law" or "identity-driven" processes. Proponents of restrictive immigration policy have argued that their stance reflects an unbiased concern with punishing individuals who break the law. If people break laws_like entering the U.S. without proper documentation or through improper administrative channels - then such individuals must be punished. There is a 
healthy amount of skepticism regarding this "rule of law" reasoning as there is anecdotal and empirical evidence that show people are more willing to punish undocumented immigrants than the U.S. employers who hire undocumented immigrants (Mukherjee et al., 2012).

Alternatively, there are critics who argue that restrictive immigration laws rather than being solely about 'rule of law' deliberately targets particular types of people-specifically Latinx/Hispanic individuals. It stands to reason that because law enforcement officials cannot approach every individual they suspect is in the country without documentation they must practice discretion about whom to approach. Discretion makes law enforcement officials susceptible to biases (e.g., Latinx $=$ undocumented) that may influence their perceptions and behaviors due to reasonable suspicion (Mukherjee et al., 2013). Police may (un-)wittingly approach more Latinx individuals (even U.S. citizens) than other community members because this cultural group fits the social representation of an undocumented immigrant. This results in both a disadvantage that certain groups (e.g., Latinx) face at the hands of the law and a privilege that other immigrant groups (e.g., Canadians) are afforded as they are not suspected of being in the U.S. illegally (Mukherjee et al., 2013).

What type of immigration policy? The present work includes numerous immigration policies that focus on: the English proficiency of immigrants (e.g., bilingual education), shoring up the nation's borders (e.g., deportation and building a wall on the Southern border), punitveness targeting outgroups (i.e., punishment of undocumented immigrants) and ingroups (i.e., punishment of American employers who hire undocumented immigrants). The first policy centers on culturally assimilating immigrants who are (legally) within the nation's borders. The next two policies focus on immigrants as a group and emphasize the notion of "getting rid of and keeping them out" of the U.S. The fourth policy focuses on one's ingroup-U.S. employers who 
hire and exploit undocumented immigrants — and the willingness of U.S. participants to hold steadfast to punishing "law breakers" even if it means punishing one's fellow group members. This puts the present research in a relatively unique position compared to other psychological research on immigrants and immigration legislation. This past research typically examines attitudes toward immigration policy in a specific form (e.g., supporting increased funding to deport undocumented immigrants). The inclusion of different types of policy affords us the capacity to examine how group identities (e.g., nationalism) play out in distinct ways as a function of the type of immigration policy.

Policing identity. Based on previous work (see Mukherjee, Molina, \& Adams, 2012) we hypothesize that what partially accounts for strong positions on immigration policy are (national) identity concerns and not simply 'rule of law' concerns. If immigration policy is solely about 'rule of law' the issue of national identity or other identity-relevant concerns (e.g., symbolic threats) should not be predictive of immigration policy.

The present research provides an empirical test of the 'law and order' account regarding immigration policy and simultaneously tests whether there is support for an 'identity-driven' account. An identity-driven account suggests that part of what explains support for punitive immigration policy is protecting or "policing" national identity (e.g., Mukherjee, Molina, \& Adams, 2013) that is distinct from 'realistic concerns' that immigrants are taking away resources (e.g., jobs, social services; Esses et al., 2001).

\section{Immigrants as "Threatening Others": Realistic and Symbolic Threats}

A cursory glance of U.S. political rhetoric regarding immigration suggests that most of the discourse focuses on realistic concerns-for instance, immigrants are taking away jobs. There are alternatives to this discourse, although they may not receive as much time and priority. 
Social psychological research on immigration, for example, typically has one of two framings:

(1) the perceived realistic threats that immigrants pose to the limited resources of the country and (2) the perceived symbolic threats that immigrants pose to the culture of the country. The former maps onto the aforementioned political rhetoric while the latter is critical but less wellrepresented in the political sphere.

Realistic threats. Studies have shown that perceptions that immigrants are taking away realistic resources (e.g., jobs, social services) predicts stronger stances on immigration policy (Esses et al., 2001; Rothschild et al., 2015). Esses et al. (2001) theorize that attitudes toward immigrants and immigration are shaped by perceptions that immigrants compete with members of the receiving society for finite resources (e.g., jobs). The perceived group competition, in turn, motivates strategies to remove the sourse of competition — by supporting anti-immigration policy. A more recent iteration of the 'realistic concern' idea regarding immigration is a concern with national security because of the "criminal and violent" element that immigrants are purported to bring to the U.S.

Symbolic threats. There is also evidence that constructions of U.S. identity as Anglocentric (e.g., speaking English as a core aspect of what it means to be American) predict stronger stances on immigration policy (see Mukherjee et al., 2013). This research does not deny the importance of realistic concerns but instead proposes that individuals may also have constructions of nation that are reflective of Anglocentric values that may, in turn, motivate people to protect the "culture" of nation by ensuring certain cultural "Others" are deported or kept out. The emphasis is on protecting one's construction of nation and ensuring that a group's sense of ownership of the nation remains in tact via tough immigration policy (Mukherjee, Adams, \& Molina, 2017; Sidanius \& Petrocik, 2001). 


\section{Present Research}

The present research focuses on immigration and examines: (1) the relative importance of patriotism and nationalism, two related but distinct forms of national identity, toward stances on immigration; and (2) whether perceptions of group threat (realistic or symbolic) account for the relationship between national identity and immigration policy. Another contribution is that we include a variety of immigration policies that focus on: language (bilingual education; S1 \& S2), restrictive immigration (e.g., building a wall on the U.S. Southern border; S1 \& S2), punitiveness toward U.S. employers who hire undocumented immigrants (S2), and punitiveness toward undocumented immigrants (S2). We include a variety of immigration policies to highlight the various policies that fall under the umbrella of immigration and to test whether the relationships between national identity and group threats vary as a function of the specific policy.

\section{Study 1}

\section{Method}

\section{Participants}

We recruited 198 participants via Amazon Mechanical Turk (mTurk; see Buhrmester et al., 2011; 2018), who each received $\$ 1.00$ payment for participation. After filtering for White/European American participants who reported that their parents were U.S. born, the combined sample consisted of 90 men and 58 women ranging in age from 20 to 68 years $(M=$ 36.22, $S D=10.67)$. See Table 1 for demographics of Study 1 sample.

\section{Measures}

Unless otherwise noted, participants for all scales responded to a 1 (strongly agree) to 7 (strongly disagree) scale to rate their agreement with each item (items taken from Sidanius, Feshbach, Levin \& Pratto, 1997). 
Nationalism. Three items were averaged to assess nationalism, which is a sense of the superiority or dominance of one's country in comparison to other countries (e.g., 'To maintain our country's economic superiority, aggressive economic policies are sometimes necessary"; $\alpha=$ .75 , reverse coded).

Patriotism. Patriotism or pride in one's country and its symbols was measured via three items (Sidanius, Feshbach, Levin \& Pratto, 1997). We averaged items to create an indicator of patriotism (e.g., "I am proud to be an American"; "I have great love for my country"; $\alpha=.90$, reverse coded)

Cultural assimilation. Three items assessed support for assimilation to U.S. cultural values (items were adapted from Hehman et al., 2012). Items were averaged to form a scale (e.g. "If people want to succeed in the U.S., they should adopt the values of my ethnic group"; $\alpha=$ .81 , reverse coded).

Language related immigration policy. Four items tapped support for English language fluency when in the U.S. The items included: "Government agencies and offices interacting directly with citizens should make documents, forms, and signs available in languages other than English"; "Individuals seeking to become legal permanent residents need to have taken some English language courses prior to the application process" (reverse coded); "In order for individuals to qualify to become permanent residents they need to demonstrate English proficiency as part of their application" (reverse coded); and "A state or local law declaring English as the Official Language." Participants indicated their agreement with the first three items using a scale of 1 (strongly agree) to 6 (strongly disagree) and their support of the last item with a scale of 1 (extremely unlikely) to 6 (extremely likely). We averaged these items to form an indicator of language related immigration policy $(\alpha=.84)$. 
Restrictive immigration policy. Two items measured support for policies designed to prevent immigrants from entering the U.S. The items included: "In the interest of national security, the government should temporarily ban Muslim immigrants from entering the USA" (reverse coded); and "The building of a wall on the border between Mexico and the USA." Participants indicated their agreement with the first item using a scale of 1 (strongly agree) to 6 (strongly disagree) and their likelihood of supporting the second item with a scale of 1 (extremely unlikely) to 6 (extremely likely). We computed the mean of these items to assess restrictive immigration policy $(\mathrm{r}=.90)$.

\section{Results}

In study 1 , we first present a summary of the inter-item correlations of key variables and then summarize hierarchical regression analyses predicting attitudes toward various immigration policies as a function of political orientation, national identity and perceived threats (e.g., cultural).

\section{Inter-item correlations}

As shown in Table 2, bivariate correlations indicated there was a significant positive relationship between patriotism and nationalism $(r=.51, p<.01)$. In addition, both patriotism $(r$ $=.35)$ and nationalism $(r=.50)$ were positively related to cultural assimilation $(p \mathrm{~s}<.01)$. These correlations with cultural assimilation are significantly different, $z=1.99, \mathrm{p}<.05$. It was also the case that both patriotism $(r=.37)$ and nationalism $(r=.42)$ were positively related to language policy $(p \mathrm{~s}<.01)$. We found a similar pattern for patriotism $(r=.39)$ and nationalism $(r=.46)$ and its relationship to restrictive immigration policy $(p \mathrm{~s}<.01)$. Both patriotism $(r=.40)$ and nationalism $(r=.42)$ were positively related to political orientation $(p s<.01)$. In addition, 
cultural assimilation $(r=.55)$, language policy $(r=.54)$ and restrictive immigration policy $(r=$ $.70)$ all had a significant positive relationship with political orientation $(p s<.01)$.

\section{Hierarchical Regressions on Immigration Policy}

Two parallel hierarchical regression analyses were conducted for language related immigration policy and restrictive immigration policy. In both analyses, political orientation was entered at Step 1 as a control variable given that past literature has demonstrated political conservatism is strongly related to punitive stances on immigration policy (Sears et al., 1999). National identity variables (nationalism and patriotism) were entered at Step 2 since previous literature has shown that national identification, particularly nationalism, is associated with more hawkish stances on immigration. Cultural assimilation was entered at Step 3 as a test of our hypothesis that negative attitudes towards immigrants and immigration are driven in part by the perception that immigrants threaten the economic and cultural well-being of U.S. citizens (Esses et al., 2001; Mukherjee et al., 2012, 2013). We first turn to the findings for language related immigration policy.

Language related immigration policy. As shown in Table 3, hierarchical multiple regression analyses revealed that at Step 1, higher political conservatism was strongly related to supporting English language fluency when in the U.S. $(\beta=.54, p<.001)$. At step 2, higher nationalism $(\beta=.19, p<.05)$ but not patriotism $(\beta=.11, p>.05)$ contributed significantly to the regression model, $F(3,145)=25.07, p<.001$ and accounted for $5 \%$ of the variation in language related immigration policy. Adding cultural assimilation $(\beta=.64, p<.001)$, at step 3 , explained an additional $25 \%$ of the variance in language policy and this change in $\mathrm{R}^{2}$ was significant, $F(1$, $144)=90.50, p<.001$. The inclusion of cultural assimilation resulted in nationalism becoming a non-significant predictor $(\beta=-.002, p>.05)$. 
In summary, the full model demonstrated that neither nationalism nor patriotism were significant predictors of language related immigration policy $(p s>.05)$. Instead, the sole significant predictors were political orientation and cultural assimilation $(p s<.05)$ such that more conservativism and support for cultural assimilation predicted more pro-English only stances in civic and political life. The overall model accounted for $58 \%$ of variance in language related immigration policy.

Restrictive immigration policy. At Step 1, higher political conservatism was strongly related to more restrictive immigration policy $(\beta=.70, p<.001$; see Table 3$)$. At step 2 , higher nationalism $(\beta=.24, p<.05)$ but not patriotism $(\beta=.06, p>.05)$ contributed significantly to the regression model, $F(3,145)=52.82, p<.001$ and accounted for $4 \%$ of the variation in restrictive immigration policy. Adding cultural assimilation $(\beta=.53, p<.001)$, at step 3 , to the regression model explained an additional $18 \%$ of the variance in restrictive immigration policy and this change in $\mathrm{R}^{2}$ was significant, $F(1,144)=90.08, p<.001$. The entry of cultural assimilation resulted in nationalism becoming a non-significant predictor $(\beta=.05, p>.05)$.

In summary, the full model indicated that neither nationalism nor patriotism were significant predictors of restrictive immigration policy $(p s>.05)$. Instead, the sole significant predictors were political orientation and cultural assimilation $(p s<.05)$ indicating that political conservatism and support for cultural assimilation predicted support for policy designed to prevent immigrants from entering the U.S. The overall model accounted for $70 \%$ of variance in restrictive immigration policy.

\section{Brief Discussion}

The first goal of Study 1 was to examine the relationship between national identity and immigration policy. Our findings suggest that nationalism, but not patriotism, drives support for 
both language related immigration policy and restrictive immigration policy even after controlling for political orientation. These results align with prior research that associates nationalism with support for authoritarian structures, intolerance towards ethnic minorities and constructions of the nation state based on race or cultural affiliation (Crowson, 2009; Mukherjee, Molina, \& Adams, 2012; Mummendey, Klink, \& Brown, 2001; Renner, Salem \& Alexandrowicz, 2004). Conversely, patriotism is associated with democracy, tolerance for minorities and a more multicultural construction of the nation state (Blank \& Schmidt, 2003).

The second goal of Study 1 was to determine whether perceptions of threat account for the relationship between national identity and immigration policy. For both types of immigration policy (language related and restrictive), the addition of cultural assimilation into the regression model fully accounted for the relationship between nationalism and immigration policy. These patterns of findings persisted even after controlling for the effect of political orientation. A potential explanation for these results is that support for harsh immigration policy is driven, at least in part, by the perception that immigrants represent a threat to the U.S. (Esses et al., 2001; Mukherjee et al., 2012, 2013).

However, one limitation of the present study is that we used cultural assimilation as a proxy measure for symbolic threat. While support for cultural assimilation is positively related to perceived symbolic threat (see Danbold \& Huo, 2015), study one's operationalization of symbolic threat (i.e., pro cultural assimilation) is not a direct measure of symbolic threat. We resolve this in study two. Another limitation of study 1 is that it does not include a measure of perceived economic threat $-a$ type of threat believed to underpin strong stances on immigration policy (Esses et al., 2001). In Study 2, we include measures of both economic and symbolic threat in order to examine what type of threat drives the relationship between national identity 
and immigration policy support. Study 2 also included additional measures of immigration policy to test whether the effects observed in Study 1 apply to additional policy contexts. For instance, we include a measure of immigration policy that targets American employers who hire undocumented immigrants as a way of examining whether identity-driven stances on immigration policy also hold when the target that is punished is one's ingroup (i.e., Americans). Study 2 also modified the coding from study 1 so that higher numbers reflected stronger agreement with each statement/item.

\section{Study 2}

\section{Method}

\section{Participants}

One hundred ninety eight participants were recruited via Amazon mTurk and received $\$ 1.00$ in exchange for participation. After filtering for White/European American participants who reported that their parents were born in the U.S., the combined sample consisted of 65 men and 70 women ranging in age from 21 to 74 years $(M=36.75, S D=11.42)$. See Table 1 .

\section{Measures}

All of the following items unless otherwise noted were on a 7-point Likert scale from 1 (strongly disagree) to 7 (strongly agree).

Nationalism. The same three items from Study 1 were used to measure nationalism $(\alpha=$ $.83)$.

Patriotism. The same three items from Study 1 were employed to asssess patriotism $(\alpha=$ $.92)$.

Realistic threat. Five items, adapted from Paxton \& Mughan (2006), were averaged to form an indicator of realistic threat, which measures the perception that immigrants represent a 
risk to "realistic" issues like the safety, economy, politics, health and well-being of American citizens (Kendall, 1998). Example items include: "Immigrants take jobs from Americans"; and "Immigrants raise taxes for Americans" $(\alpha=.94)$.

Symbolic threat. The perception that immigrants represent a risk to the morals, standards, attitudes, beliefs and values of America was measured via five items (Oskamp, 2000; Van Acker et al., 2014). Sample items include: "Immigrant groups have values and traditions that cannot be reconciled with American values and traditions"; and "The way of life of some immigrant groups does not fit with the American way of life." We averaged the items to form an indicator of symbolic threat $(\alpha=.93)$.

Language related immigration policy. The same four items from Study 1 were used to tap language related immigration policy $(\alpha=.87)$. Participants indicated their agreement with each item using a scale of 1 (strongly disagree) to 6 (strongly agree).

Restrictive immigration policy. One additional item ("The immediate deportation of all undocumented immigrants") was added to the scale from Study 1 to form a 3-item indicator of restrictive immigration policy $(\alpha=.94)$ Participants used a scale of 1 (extremely unlikely) to 6 (extremely likely) to rate their support for each item.

American employer focused policy. Three items were averaged to measure support for policy that targets and punishes the American employers who hire undocumented immigrants $(\alpha$ $=.86)$. Items included "Impose heavy fines on US employers that knowingly hire undocumented immigrants"; "Pass legislation that requires all employers to verify the citizenship status of newly hired employees"; and "Prosecute and punish American businesses who exploit illegal immigrants for their labor and other services." Participants used a scale of 1 (not at all important) 
to 5 (extremely important) to rate the urgency of these policies for adoption by the U.S. government.

Immigrant focused policy. We also included two items that focus on policies that target immigrants: "Pass legislation that gives states the right to question people about their immigration status if they are suspected of being in the U.S. illegally"; and "Pass legislation that gives states the right to detain anyone without proper identification who is suspected of being in the U.S. illegally." We averaged the items to form an indicator of Immigrant focused policy $(\mathrm{r}=$ .94). Participants used a scale of 1 (not at all important) to 5 (extremely important) to rate the urgency of these policies for adoption by the U.S. government.

\section{Results}

Study 2 , similar to study 1 , presents a summary of the inter-item correlations of variables and summarizes hierarchical regression analyses predicting attitudes toward various immigration policies as a function of political orientation, national identity and perceived threats (e.g., symbolic and realistic).

\section{Inter-item correlations}

As shown in Table 4, bivariate correlations indicated there was a significant positive relationship between patriotism and nationalism $(r=.52, p<.01)$. In addition, both patriotism $(r$ $=.34)$ and nationalism $(r=.52)$ were positively related to realistic threat $(p \mathrm{~s}<.01)$. These correlations with realistic threat are significantly different, $\mathrm{Z}=2.43, p<.01$. Patriotism $(r=.39)$ and nationalism $(r=.57)$ were also positively related to symbolic threat $(p \mathrm{~s}<.01)$ and the correlations are significantly different, $\mathrm{Z}=2.15, p<.01$. It was also the case that both patriotism $(r=.30)$ and nationalism $(r=.45)$ were positively related to language policy $(p \mathrm{~s}<.01)$. We found a similar pattern for patriotism $(r=.38)$ and nationalism $(r=.53)$ and its relationship to 
restrictive immigration policy $(p \mathrm{~s}<.01)$. This general pattern emerged consistently for patriotism and nationalism and their relationship to both American employer focused policy and immigrant focused policy. Both patriotism $(r=.49)$ and nationalism $(r=.60)$ were positively related to political orientation $(p s<.01)$. It is also the case that both realistic threat $(r=.69)$ and symbolic threat $(r=.67)$ were positively related to political orientation $(p s<.01)$. In addition, American employer policy $(r=.47)$ and immigrant focused policy $(r=.72)$ all had a significant positive relationship with political orientation $(p s<.01)$.

\section{Hierarchical Regressions on Immigration Policies}

Parallel hierarchical regression analyses were conducted for language related immigration policy, restrictive immigration policy, American employer focused policy, and immigrant focused policy. Similar to study 1, all analyses included political orientation as a control variable at Step 1. National identity variables (nationalism and patriotism) were entered at Step 2. Realistic and symbolic threat were entered at Step 3 as a direct test of our hypothesis that support for restrictive immigration policy is driven in part by the perception that immigrants threaten the economic and cultural well-being of American citizens. We first turn to the findings for language related immigration policy.

Language related immigration policy. As shown in Table 5, hierarchical multiple regression analyses revealed that at Step 1, higher political conservatism was strongly related to supporting English language fluency when in the U.S. $(\beta=.63, p<.001)$. At step 2 , higher nationalism $(\beta=.23, p<.05)$ but not patriotism $(\beta=-.12, p>.05)$ contributed significantly to the regression model, $F(3,132)=33.29, p<.001$ and accounted for $3 \%$ of the variance. When added to the model at Step 3, symbolic threat $(\beta=.52, p<.001)$ but not realistic threat $(\beta=.13$, $p>.05)$ explained an additional $18 \%$ of the variance and this change in $\mathrm{R}^{2}$ was significant, $F(2$, 
$130)=30.07, p<.001$. The entry of symbolic threat resulted in nationalism becoming a nonsignificant predictor $(\beta=.01, p>.05)$. In summary, the full model demonstrated that the sole significant predictors were political orientation and symbolic threat $(p s<.05)$ such that political conservatism and the perception that immigrants threaten American values predicted support for pro-English only stances in civic and political life. The overall model accounted for $60 \%$ of variance in language related immigration policy.

Restrictive immigration policy. Step 1 of the hierarchical regression analysis revealed that higher political conservatism was strongly related to more restrictive immigration policy $(\beta$ $=.77, p<.001 ;$ see Table 5$)$. At step 2 , higher nationalism $(\beta=.24, p<.01)$ but not patriotism $(\beta$ $=.06, p>.05)$ contributed significantly to the regression model, $F(3,132)=72.91, p<.001$ and accounted for $3 \%$ of the variance. Adding realistic threat $(\beta=.33, p<.001)$ and symbolic threat $(\beta=.30, p<.001)$, at step 3 , to the regression model explained an additional $16 \%$ of the variance and this change in $\mathrm{R}^{2}$ was significant, $F(2,130)=49.87, p<.001$. The entry of perceived threat resulted in nationalism becoming a non-significant predictor $(\beta=.04, p>.05)$. The full model showed that the only significant predictors were political orientation, realistic threat and symbolic threat $(p s<.05)$. These findings indicate that political conservatism and the perception that immigrants threaten American values and the safety and economic well-being of American citizens predicts support for policy designed to prevent immigrants from entering the U.S. The overall model accounted for $78 \%$ of variance in restrictive immigration policy.

\section{American employer focused policy. Step 1 demonstrated that higher political} conservatism was strongly related to supporting policy that punished American employers who hired undocumented immigrants $(\beta=.47, p<.001)$. Although the overall model was significant $F(3,132)=14.34, \mathrm{p}<.001$, only patriotism $(\beta=.21, p<.05)$ was a significant predictor of 
American employer focused policy at step 2 . The addition of national identity variables to the model did not result in a significant $\mathrm{R}^{2}$ change. When added to the model at Step 3, symbolic threat $(\beta=.36, p<.05)$ but not realistic threat $(\beta=.05, p>.05)$ explained an additional $8 \%$ of the variance in American employer focused policy and this change in $\mathrm{R}^{2}$ was significant, $F$ (2, $130)=7.44, p<.01$. The entry of symbolic threat resulted in nationalism becoming a significant predictor $(\beta=-.25, p<.05)$ and political orientation becoming a non-significant predictor $(\beta=$ $.20, p>.05)$. When all the predictors were included in the model nationalism, patriotism and symbolic threat were significant predictors of American employer focused policy $(p s<.05)$. These findings indicate that a sense of national pride, a belief that America is superior to other countries and the perception that immigrants threaten American morals and values predicts support for policy that punishes American employers who hire undocumented immigrants. Political orientation and realistic threat were non-significant predictors $(p \mathrm{~s}<.05)$. The overall model accounted for 30\% of variance in American employer focused policy.

Immigrant focused policy. Hierarchical regression analyses revealed that at Step 1, higher political conservatism was strongly related to support for policy that targets immigrants. $(\beta=.72, p<.001 ;$ see Table 5$)$. At step 2 , neither nationalism $(\beta=.07, p>.05)$ nor patriotism $(\beta$ $=-.009, p>.05)$ contributed significantly to the regression model. When added to the model at Step 3, realistic threat $(\beta=.41, p<.001)$ but not symbolic threat $(\beta=.18, p>.05)$ explained an additional $12 \%$ of the variance in immigrant focused policy and this change in $\mathrm{R}^{2}$ was significant, $F(2,130)=20.70, \mathrm{p}<.001$. When all the predictors were included in the model only political orientation and realistic threat were significant predictors of immigrant focused policy (ps <.05) such that increased political conservatism and the perception that immigrants represent a risk to the safety and well-being of American citizens predicted more support for policy that 
target suspected undocumented immigrants. The overall model accounted for $62 \%$ of variance in immigrant focused policy.

\section{Brief Discussion}

Study 2 sought to replicate and extend Study 1 findings in a new sample. In order to address potential limitations of study 1 , we included direct measures of perceived realistic and symbolic threat. We also included additional immigration policy items to assess if the patterns from Study 1 persisted under more diverse policy contexts.

Similar to Study 1, nationalism but not patriotism significantly predicted support for both language related immigration policy and restrictive immigration policy at Step 2 of the model. Conversely, patriotism was the only significant predictor of support for policy that punished American employers who hire undocumented immigrants. This result supports our hypothesis that a more patriotic construction of national identity may be associated with a greater willingness to acknowledge how American citizens participate in and benefit from immigration. Contrary to our predictions, neither nationalism nor patriotism was a significant predictor of support for policy that targets suspected undocumented immigrants. These findings persisted even after controlling for the effects of political orientation.

The addition of symbolic threat (but not realistic threat) to the model fully accounted for the relationship between nationalism, patriotism and language related immigration policy. This is consistent with prior work that suggests that concerns about immigrants changing what it means to be "American" underlie negative attitudes towards immigrants and support for more hawkish stances on immigration (Mukherjee et al., 2012). In the case of restrictive immigration policy, symbolic and realistic threat fully accounted for its relationship with national identity. For both 
language related and restrictive immigration policy, these findings persisted even after controlling for the effect of political orientation.

The pattern of results for the additional immigration policy items were more variable.

Even after the addition of symbolic threat to the model, patriotism remained a significant predictor of support for policy that focused on punishing American employers. After the inclusion of symbolic threat, nationalism unexpectedly emerged as a significant predictor while the effects of political orientation dropped out altogether. After controlling for political orientation, realistic threat was the only significant predictor of support for policy targeting suspected undocumented immigrants.

\section{General Discussion}

The present research adds to the growing psychological literature examining how group identities inform stances on immigration (see Esses et al., 2001; Mukherjee et al., 2012). Across two studies we test how various U.S. immigration policies are predicted by national identity (i.e., patriotism and nationalism) and perceived group threats (e.g., symbolic and realistic). We demonstrate that national identity positively predicts strong stances on immigration policy thereby replicating past research. Furthermore, one of the key contributions of the present work is that inclusion of symbolic threats attenuate the relationship between nationalism and tough stances on immigration policy but not the relationship between patriotism and immigration policy. The present findings also extend previous research (Mukherjee et al., 2012) by providing evidence that symbolic threats (e.g., immigrants change what it means to be American) partially underpin the relationship between nationalism and tough stances on immigration. Finally, the type of policy in question matters for the above relationships.

\section{National Identity: Critical and Glorifying Forms}


The political psychological literature includes various measures of national identity (e.g., Kosterman \& Feshbach, 1989; Schatz, Staub, \& Levine, 1999; Hechter, 2000; Schatz \& Staub, 1997; Meloen et al., 1999). One of the seminal conceptualizations of national identity is the distinction made between patriotism and nationalism (Kosterman \& Feshbach, 1989). Patriotism is defined as love for one's nation and its symbols (e.g., U.S. flag) with an openness to being critical of one's nation (Schatz et al., 1999). Nationalism, on the other hand, is defined as perceiving that one's nation is superior and dominant to other countries and is characterized by valorizing one's country as being 'exceptional.' The present research examines how critical forms of national identity differ from glorifying forms when it comes to supporting immigration policy.

Findings typically showed that nationalism, but not patriotism, was a predictor of strong support for restrictive immigration policy. In addition, this relationship between nationalism and immigration legislation typically became non-significant when perceived group threats (cultural assimilation in Study 1 and symbolic threat in Study 2) were introduced into the regression. This pattern suggests: (1) strong stances on immigration policy reflect endorsement of a more belligerent and glorifying national identity; and (2) the association between nationalism and restrictive immigration policy is underpinned by perceived group threats that reveal fears of the nation changing as a function of the "influx" of immigrants (i.e., symbolic threat).

Similar to past research, patriotism was a moderate positive predictor of punitiveness toward U.S. employers who hire undocumented immigrants (see Mukherjee et al., 2012). This was in the context of higher levels of nationalism predicting less support for punishing the same U.S. employers. We interpret this as evidence of patriotism (a relatively more critical form of national identity) demonstrating a more egalitarian application of punitiveness toward people 
who "break the law" even if those people include one's ingroup members. Whereas the findings for higher levels of nationalism suggests that U.S. employers should not be punished thereby signaling a discretionary application of "rule of law" in which one's ingroup members do not warrant punishment despite the fact that they hire and exploit undocumented immigrants. This is the only instance across our two studies and multiple outcomes in which nationalism remains significant in the last step of the regression. It suggests that constructing one's nation as exceptional places ingroup members in a privileged position whereby they are above the "scope of justice" (Opotow, 2018). Finally, without including multiple forms of immigration policy we would not have been able to document how certain forms of national identity (e.g., patriotism) do not matter for certain legislative arenas (e.g., restrictive immigration policy) but do matter in other arenas (e.g., punishing U.S. employers who hire undocumented immigrants).

\section{Group Threats: Realistic and Symbolic}

Social scientists typically approach understanding attitudes toward immigration policy as a function of people's perceived realistic threats or symbolic threats. In the former case, the perception that immigrants are "taking away jobs" or a burden on limited resources (e.g., social welfare) predicts stronger stances on immigration as a function of a perceived "zero sum" relationship tied to perceived realistic group conflict (see Esses et al., 2001). The case of symbolic threats suggests that individuals care about the threat that immigrants pose to constructions of U.S. identity such that immigrants "change the meaning" of what it means to be ‘American’ (see Danbold \& Huo, 2015; Mukherjee et al, 2017). The present research included these two group threats in order to examine how they relate to different forms of national identity and whether one or both are critical to understanding stances on immigration policy. 
Bivariate correlations demonstrate that perceived group threats—-symbolic and realistic are positively related to national identity—nationalism and patriotism — and a variety of immigration policies. Across both studies, the series of hierarchical regressions provided a general pattern in which nationalism dropped out as a predictor when perceived group threat was entered into the regression for language immigration policy and restrictive immigration policy. For immigration policy that targets American employers who hire undocumented immigrants we found that symbolic threat (but not realistic threat) was positively related to strong endorsement of this policy. However, when the immigration policy targets solely undocumented immigrants we found that realistic threat (but not symbolic threat) was positively related to policy endorsement.

A fairly consistent pattern emerges suggesting that there is a moderate to strong predictive relationship for symbolic threat toward many of the immigration policies. Higher perceptions that (undocumented) immigrants are changing what it means to be American predicts more punitive stances on a variety of immigration policies: making English the 'official' language of the U.S and support for "building a wall" to shore up the U.S.-Mexico border. Laws are purported to be "free" of identity-concerns and solely about 'rule of law' yet our findings suggests that U.S. immigration legislation is informed by group identity — specifically, about protecting certain constructions of what it means to be American (see Devos \& Banaji, 2005; Sidanius \& Petrocik, 2001; Van Berkel, Molina, \& Mukherjee, 2017).

With regards to perceived realistic threat, our findings for immigration policy are less consistent but nonetheless important. Specifically, realistic threat was a significant predictor of restrictive immigration policy and policy targeting undocumented immigrants. Findings suggest the perception that (undocumented) immigrants are taking away jobs predict policy designed to 
prevent immigrants from entering the U.S. and punish undocumented immigrants but not the American employers who hire them.

Immigration Policy as 'Policing Identity'. One can frame the present findings for national identity, symbolic threat and immigration policy as reflective of 'policing identity.' What we mean by this is that individuals may have specific conceptions of what it means to be American (e.g., speaking English, being White) which predicts tough stances on immigration. The 'real world' implications of immigration policy is that it prohibits certain types of people from entering the country and provides a legal and political mechanism for jettisoning certain groups of people that are already in the country. Latin American individuals would most likely be the target of such policy while immigrants from other nations such as Canada and England would not be targeted. The result is that policy can indirectly "police identity" and its symbolic values by shaping the ethnic/racial composition of the nation under the guise of 'rule of law.' We should note that the perceived realistic threat of immigrants (e.g., a drain on our resources) can be divorced from the objective reality and that the facts on the ground do not necessarily have to provide support for this perception. Although not empirically tested, to our knowledge, it stands to reason that individuals may deploy 'realisitic concerns' because they afford the individual a justification to express genuine prejudice they otherwise may not feel is socially acceptable to express (see Crandall \& Eshleman, 2003)

\section{Limitations and Future Directions}

The present study has several limitations. First, both studies are correlational and so no causal claims can be made about the effects of national identity or group threats on attitudes toward immigration policy. This, however, was not the aim of the present research. Rather, this work sought to replicate past research that demonstrated a relationship between national identity 
(e.g., patriotism, nationalism) and attitudes toward immigration policy. The present work also extended this past work by (1) examining the relationship of national identity to group threats and (2) examining national identity and group threats in the context of two under-examined immigration policies (i.e., language policy and restrictive policy). Future research can experimentally manipulate the salience of different forms of national identity and/or different group threats and assess how they affect stances on immigration policy.

Second, the pattern of findings we show across both studies are based on White, U.S. born participants. Future research should examine how group identities and perceived group threats play out for ethnic/racial minorities (e.g., African-Americans, Latin Americans) with regards to attitudes toward immigration. It is not necessarily clear that African-Americans, for example, will mimic the patterns found for White Americans. Given the increasing diversity and demographic changes in the U.S. whereby it will be a majority-minority nation (see Craig \& Richeson, 2014; Danbold \& Huo, 2015) it becomes important to understand how other ethnic/racial groups think of immigration — in particular, for ethnic/racial groups who may have a relatively recent immigration history (e.g., Latinx-Americans, Asian Americans). It will also be important to consider how differential representations of ethnic/racial groups (e.g. LatinxAmericans $=$ criminal, Asian American $=$ model minority $)$ in popular cultural and political discourse affect minority group attitudes towards immigration.

Third, the present research was conducted in a U.S. context and it remains an empirical question as to whether the pattern of relationships can be replicated in national contexts that are not WEIRD (Western, Educated, Industrialized, Rich, and Democratic; Henrich, Heine, \& Norenzayan, 2010) settings where immigration and immigration policy are salient issues within the socio-political environment. Moreover, are the present patterns of relationships specific to a 
U.S. context or do they carry over to countries/regions with different immigration histories, prototypes for "the immigrant" and constructions of national identity? Future research needs to examine similar and additional questions in order to determine how generalizable our findings are to other national contexts where immigration is a critical social issue.

\section{Concluding Remarks}

The present research makes a contribution to the psychological literature on immigrants and immigration by demonstrating that different forms of national identity and group-based threats inform these attitudes. In brief, there is fairly consistent evidence that identity concernswhether they be symbolic/realistic threat or national identity - play a role in predicting strong stances. Thinking of one's nation as exceptional or evaluating immigrants as a threat to the nation's culture predicts fairly strong anti-immigration stances.

Immigration is a potent issue in the U.S. and worldwide. The writing on the wall foreshadows that it will garner more socio-political prominence as many nations, including the U.S., have taken a turn toward nativism and xenophobia. The present research suggests that employing certain forms of national identity, such as nationalism, and amplifying the perceived threats that immigrants pose to the U.S. should result in stronger anti-immigrant and antiimmigration attitudes. It should come as no surprise then that when one looks at the U.S. political landscape that nationalism and the threats that immigrants pose are mainstream fare ("building a wall” to keep people from Latin America out of the U.S. seems plausible) and highly punitive immigration policy (e.g., the separation of children from their parents at the border) has become the new norm. 


\section{References}

Anderson, B. (1983). Imagined communities: Reflections on the origin and spread of nationalism, 427-449.

Bar-Tal, D. E., \& Staub, E. E. (1997). Patriotism: In the lives of individuals and nations. NelsonHall Publishers.

Blank, T., \& Schmidt, P. (2003). National identity in a united Germany: Nationalism or patriotism? An empirical test with representative data. Political Psychology, 24(2), 289312.

Brubaker, R. (1996). Nationalism reframed: Nationhood and the national question in the new Europe. Cambridge University Press.

Buhrmester, M., Kwang, T., \& Gosling, S. D. (2011). Amazon's Mechanical Turk: A new source of inexpensive, yet high-quality, data?. Perspectives on psychological science, 6(1), 3-5.

Buhrmester, M. D., Talaifar, S., \& Gosling, S. D. (2018). An evaluation of Amazon's Mechanical Turk, its rapid rise, and its effective use. Perspectives on Psychological Science, 13(2), 149-154.

Craig, M. A., \& Richeson, J. A. (2014). On the precipice of a "majority-minority" America: Perceived status threat from the racial demographic shift affects White Americans' political ideology. Psychological Science, 25(6), 1189-1197.

Crandall, C. S., \& Eshleman, A. (2003). A justification-suppression model of the expression and experience of prejudice. Psychological bulletin, 129(3), 414.

Crowson, H. M. (2009). Are all conservatives alike? A study of the psychological correlates of cultural and economic conservatism. The Journal of psychology, 143(5), 449-463.

Danbold, F., \& Huo, Y. J. (2015). No longer “All-American”? Whites’ defensive reactions to 
their numerical decline. Social Psychological and Personality Science, 6(2), 210-218

Devos, T., \& Banaji, M. R. (2005). American= white?. Journal of personality and social psychology, 88(3), 447.

Esses, V. M., Dovidio, J. F., Jackson, L. M., \& Armstrong, T. L. (2001). The immigration dilemma: The role of perceived group competition, ethnic prejudice, and national identity. Journal of Social issues, 57(3), 389-412.

Hechter, M. (2000). Nationalism and rationality. Studies in Comparative International Development (SCID), 35(1), 3-19.

Hehman, E., Gaertner, S. L., Dovidio, J. F., Mania, E. W., Guerra, R., Wilson, D. C., \& Friel, B. M. (2012). Group status drives majority and minority integration preferences. Psychological Science, 23(1), 46-52.

Henrich, J., Heine, S. J., \& Norenzayan, A. (2010). The weirdest people in the world?. Behavioral and brain sciences, 33(2-3), 61-83.

Kendall, R. (1998). Anxiety, fear contribute to prejudice, say NMSU professors. Retrieved from http://www.nmsu.edu/ ucomm/Releases/1998/Nov98/stephan2.html

Kosterman, R., \& Feshbach, S. (1989). Toward a measure of patriotic and nationalistic attitudes. Political psychology, 257-274.

Markus, H. R. (2017). American=independent?. Perspectives on Psychological Science, 12(5), 855-866.

Meloen, J., De Witte, H., \& Van Der Linden, G. (1999). Authoritarianism and voting for a racist party in Belgian Flanders. Politics, groups and the individual. International Journal of Political Psychology and Political Socialization, 8, 21-40.

Molina, L. E., Phillips, N. L., \& Sidanius, J. (2015). National and ethnic identity in the face of 
discrimination: Ethnic minority and majority perspectives. Cultural Diversity and Ethnic Minority Psychology, 21(2), 225.

Mukherjee, S., Adams, G., \& Molina, L. E. (2018). Support for Tough Immigration Policy: Identity Defense or Concern for Law and Order?. Journal of Social Issues, 74(4), 700715.

Mukherjee, S., Molina, L. E., \& Adams, G. (2012). National identity and immigration policy: Concern for legality or ethnocentric exclusion?. Analyses of Social Issues and Public Policy, 12(1), 21-32.

Mukherjee, S., Molina, L. E., \& Adams, G. (2013). "Reasonable suspicion” about tough immigration legislation: Enforcing laws or ethnocentric exclusion?. Cultural Diversity and Ethnic Minority Psychology, 19(3), 320.

Mummendey, A., \& Wenzel, M. (1999). Social discrimination and tolerance in intergroup relations: Reactions to intergroup difference. Personality and Social Psychology Review, 3(2), 158-174.

Mummendey, A., Klink, A., \& Brown, R. (2001). Nationalism and patriotism: National identification and out-group rejection. British Journal of Social Psychology, 40(2), 159172.

Nagel, J. (1998). Masculinity and nationalism: Gender and sexuality in the making of nations. Ethnic and Racial Studies, 21 (2), 242-269.

Opotow, S. (2018). Social justice theory and practice: Fostering inclusion in exclusionary contexts. The Oxford handbook of social psychology and social justice, 41-58.

Oskamp, S. (2000). A sustainable future for humanity? How can psychology help?. American Psychologist, 55(5), 496. 
Paxton, P., \& Mughan, A. (2006). What's to fear from immigrants? Creating an assimilationist threat scale. Political Psychology, 27(4), 549-568.

Reicher, S., \& Hopkins, N. (2001). Psychology and the end of history: A critique and a proposal for the psychology of social categorization. Political Psychology, 22(2), 383-407.

Renner, W., Salem, I., \& Alexandrowicz, R. (2004). Human values as predictors for political, religious and health-related attitudes: A contribution towards validating the Austrian Value Questionnaire (AVQ) by structural equation modeling. Social Behavior and Personality: an international journal, 32(5), 477-490.

Schatz, R. T., \& Staub, E. (1997). Manifestations of blind and constructive patriotism: Personality correlates and individual-group relations.

Schatz, R. T., Staub, E., \& Lavine, H. (1999). On the varieties of national attachment: Blind versus constructive patriotism. Political Psychology, 20(1), 151-174.

Sidanius, J., \& Petrocik, J. R. (2001). Communal and national identity in a multiethnic state. Social identity, intergroup conflict and conflict resolution, 101-127.

Sidanius, J., Feshbach, S., Levin, S., \& Pratto, F. (1997). The interface between ethnic and national attachment: Ethnic pluralism or ethnic dominance?. The Public Opinion Quarterly, 61(1), 102-133.

Staerklé, C., Sidanius, J., Green, E. G., \& Molina, L. E. (2010). Ethnic minority-majority asymmetry in national attitudes around the world: A multilevel analysis. Political Psychology, 31(4), 491-519.

Van Acker, K., Phalet, K., Deleersnyder, J., \& Mesquita, B. (2014). Do "they" threaten "us" or 
do "we" disrespect "them": Majority perceptions of intergroup relations and everyday contacts with immigrant minorities. Group Processes \& Intergroup Relations, 17(5), 617-628.

Van Berkel, L., Molina, L. E., \& Mukherjee, S. (2017). Gender asymmetry in the construction of American national identity. Psychology of Women Quarterly, 41(3), 352-367. 
Table 1

Demographics for Study 1 and Study 2

\begin{tabular}{|c|c|c|}
\hline Variables & $\begin{array}{l}\text { Study } 1 \\
(\mathrm{~N}=149)\end{array}$ & $\begin{array}{l}\text { Study } 2 \\
(\mathrm{~N}=136)\end{array}$ \\
\hline Age & $36.16(10.76)$ & $36.75(11.42)$ \\
\hline Gender & $61.1 \%$ Male & $47.8 \%$ Male \\
\hline Political Orientation & $2.91(2.23)$ & $3.07(2.13)$ \\
\hline Some high school & -- & $1.5 \%$ \\
\hline High school graduate & $10.1 \%$ & $14.7 \%$ \\
\hline Some college & $31.5 \%$ & $31.6 \%$ \\
\hline Trade/technical/vocational training & $7.4 \%$ & $3.7 \%$ \\
\hline College graduate & $42.3 \%$ & $37.5 \%$ \\
\hline Some postgraduate work & $3.4 \%$ & $2.9 \%$ \\
\hline Post graduate degree & $5.4 \%$ & $8.1 \%$ \\
\hline Less than $\$ 10,000$ & $6.0 \%$ & $7.4 \%$ \\
\hline$\$ 10,000-\$ 19,999$ & $17.4 \%$ & $8.8 \%$ \\
\hline$\$ 20,000-\$ 29,999$ & $14.8 \%$ & $15.4 \%$ \\
\hline$\$ 30,000-\$ 39,999$ & $9.4 \%$ & $14.7 \%$ \\
\hline$\$ 40,000-\$ 49,999$ & $9.4 \%$ & $10.3 \%$ \\
\hline$\$ 50,000-\$ 59,999$ & $10.7 \%$ & $8.8 \%$ \\
\hline$\$ 60,000-\$ 69,999$ & $5.4 \%$ & $7.4 \%$ \\
\hline$\$ 70,000-\$ 79,999$ & $4.7 \%$ & $9.6 \%$ \\
\hline$\$ 80,000-\$ 89,999$ & $6.0 \%$ & $5.1 \%$ \\
\hline$\$ 90,000-\$ 99,999$ & $6.0 \%$ & $2.2 \%$ \\
\hline$\$ 100,000-\$ 149,999$ & $7.4 \%$ & $8.8 \%$ \\
\hline$\$ 150,000$ or more & $2.7 \%$ & $1.5 \%$ \\
\hline
\end{tabular}


Table 2

Means, SDs and Correlations for Variables of Study $1(N=149)$

\begin{tabular}{|c|c|c|c|c|c|c|c|c|c|}
\hline Variables & $\alpha$ & Mean & SD & 1 & 2 & 3 & 4 & 5 & 6 \\
\hline $\begin{array}{l}\text { 1. Political } \\
\text { Orientation }\end{array}$ & -- & 2.90 & 2.23 & -- & & & & & \\
\hline 2. Patriotism & .90 & 5.01 & 1.60 & $.40 * *$ & -- & & & & \\
\hline 3. Nationalism & .75 & 3.89 & 1.25 & $.42 * *$ & $.51 * *$ & -- & & & \\
\hline $\begin{array}{l}\text { 4. Cultural } \\
\text { Assimilation }\end{array}$ & .81 & 3.11 & 1.62 & $.55 * *$ & $.35 * *$ & $.50 * *$ & -- & & \\
\hline $\begin{array}{l}\text { 5. Language } \\
\text { Policy }\end{array}$ & .84 & 3.49 & 1.33 & $.54 * *$ & $.37 * *$ & $.42 * *$ & $.75^{* *}$ & -- & \\
\hline $\begin{array}{l}\text { 6. Restrictive } \\
\text { Immigration }\end{array}$ & .89 & 2.84 & 1.85 & $.70 * *$ & $.39 * *$ & $.46^{* *}$ & $.77 * *$ & $.70 * *$ & -- \\
\hline
\end{tabular}

**Correlation is significant at the 0.01 level ( 2 tailed $)$ 
Table 3

Hierarchical Regression Analyses of Immigration Policies Regressed on Political Orientation, National Identification and Cultural Assimilation (Study 1, N=149)

\begin{tabular}{|c|c|c|c|c|c|c|}
\hline \multirow[b]{2}{*}{ Variables } & \multicolumn{3}{|c|}{ Language Policy (LP) } & \multicolumn{3}{|c|}{ Restrictive Immigration (RI) } \\
\hline & Step 1 & Step 2 & Step 3 & Step 1 & Step 2 & Step 3 \\
\hline $\begin{array}{l}\text { Political } \\
\text { Orientation }\end{array}$ & $.536^{*}$ & $.411 *$ & $.149 *$ & $.697 *$ & $.560 *$ & $.365^{*}$ \\
\hline Patriotism & - & .107 & .089 & - & .061 & .044 \\
\hline Nationalism & - & $.193 *$ & -.002 & - & $.236^{*}$ & .049 \\
\hline $\begin{array}{l}\text { Cultural } \\
\text { Assimilation }\end{array}$ & - & - & $.64 *$ & - & - & $.530 *$ \\
\hline $\begin{array}{l}\mathrm{R}^{2} \text { change } \\
\text { Total } \mathrm{R}^{2}\end{array}$ & $\begin{array}{c}.287^{*} \\
.282 *(.287)\end{array}$ & $\begin{array}{c}.054^{*} \\
.328^{*}(.342)\end{array}$ & $\begin{array}{c}.254^{*} \\
.584^{*}(.596)\end{array}$ & $\begin{array}{c}.486^{*} \\
.482^{*}(.486)\end{array}$ & $\begin{array}{c}.037^{*} \\
.512 *(.522)\end{array}$ & $\begin{array}{c}.184^{*} \\
.698 *(.706)\end{array}$ \\
\hline
\end{tabular}

*indicate significant standardized beta coefficients and $\mathrm{R}^{2}$ values, ( ) indicate non-adjusted total $\mathrm{R}^{2}$ values 
Table 4

Means, SDs and Correlations for Variables of Study $2(N=136)$

\begin{tabular}{|c|c|c|c|c|c|c|c|c|c|c|c|c|}
\hline Variables & $\alpha$ & Mean & SD & 1 & 2 & 3 & 4 & 5 & 6 & 7 & 8 & 9 \\
\hline $\begin{array}{l}\text { 1. Political } \\
\text { Orientation }\end{array}$ & -- & 3.07 & 2.13 & - & & & & & & & & \\
\hline 2. Patriotism & .92 & 5.06 & 1.56 & $.49 * *$ & -- & & & & & & & \\
\hline 3. Nationalism & .83 & 4.06 & 1.46 & $.52 * *$ & $.60 * *$ & -- & & & & & & \\
\hline 4. $\mathrm{RT}$ & .94 & 3.29 & 1.72 & $69 * *$ & $.34 * *$ & $.52 * *$ & -- & & & & & \\
\hline 5. ST & .93 & 3.50 & 1.63 & $.67 * *$ & $.39 * *$ & $.57 * *$ & $.84^{* *}$ & -- & & & & \\
\hline 6. LP & .87 & 4.00 & 1.33 & $63 * *$ & $.30 * *$ & $.45^{* *}$ & $.70^{* * *}$ & $.76^{* * *}$ & -- & & & \\
\hline 7. RI & .94 & 2.82 & 1.81 & $77 * *$ & $.38 * *$ & $.53 * *$ & $.83^{* *}$ & $.81^{* *}$ & $.66 * *$ & -- & & \\
\hline 8. American & .86 & 3.62 & 1.22 & $.47 * *$ & $.35 * *$ & $.24 * *$ & $.45^{* * *}$ & $.50 * *$ & $.54 * *$ & $.47 * *$ & -- & \\
\hline 9. Immigrant & .94 & 2.69 & 1.45 & $.72 * *$ & $.37 * *$ & $.42 * *$ & $.74 * *$ & $.68 * *$ & $.71 * *$ & $.81^{* *}$ & $.63^{* *}$ & - \\
\hline
\end{tabular}

**Correlation is significant at the 0.01 level ( 2 tailed) 
Table 5

Hierarchical Regression Analyses of Immigration Policies Regressed on Political Orientation,

National Identification and Perceived Threats (Study 2, N=136)

\begin{tabular}{|c|c|c|c|c|c|c|c|c|c|c|c|c|}
\hline \multirow[b]{2}{*}{ Variables } & \multicolumn{3}{|c|}{ Language Policy } & \multicolumn{3}{|c|}{$\begin{array}{c}\text { Restrictive } \\
\text { Immigration }\end{array}$} & \multicolumn{3}{|c|}{$\begin{array}{l}\text { American } \\
\text { Employers }\end{array}$} & \multicolumn{3}{|c|}{$\begin{array}{l}\text { Undocumented } \\
\text { Immigrants }\end{array}$} \\
\hline & S1 & S2 & S3 & S1 & S2 & S3 & S1 & S2 & S3 & S1 & S2 & S3 \\
\hline Pol. Orien. & $.633^{*}$ & $.574 *$ & $.226^{*}$ & $.768^{*}$ & $.700^{*}$ & $.341^{*}$ & $.470^{*}$ & $.421^{*}$ & .199 & $.717^{*}$ & $.686^{*}$ & $.381^{*}$ \\
\hline Patriotism & - & -.116 & -.061 & - & -.114 & -.046 & - & $.205^{*}$ & $.239 *$ & - & -.009 & .055 \\
\hline Nationalism & - & $.227^{*}$ & .009 & - & $.241^{*}$ & .039 & - & -.100 & $-.242^{*}$ & - & .068 & -.091 \\
\hline RT & - & - & .127 & - & - & $.334^{*}$ & - & - & .053 & - & - & $.406^{*}$ \\
\hline ST & - & - & $.519 *$ & - & - & $.302^{*}$ & - & - & $.364^{*}$ & - & - & .117 \\
\hline $\mathrm{R}^{2}$ change & $.401 *$ & $.030^{*}$ & $.180^{*}$ & $.590^{*}$ & $.033^{*}$ & $.163^{*}$ & $.221 *$ & .025 & $.077^{*}$ & $.514^{*}$ & .003 & $.117^{*}$ \\
\hline Total $\mathrm{R}^{2}$ & $\begin{array}{l}.397 * \\
(.401)\end{array}$ & $\begin{array}{l}.418^{*} \\
(.431)\end{array}$ & $\begin{array}{l}.596^{*} \\
(.611)\end{array}$ & $\begin{array}{l}.587 * \\
(.590)\end{array}$ & $\begin{array}{l}.615^{*} \\
(.624)\end{array}$ & $\begin{array}{l}.779 * \\
(.787)\end{array}$ & $\begin{array}{l}.215^{*} \\
(.221)\end{array}$ & $\begin{array}{l}.229 * \\
(.246)\end{array}$ & $\begin{array}{l}.297 * \\
(.323)\end{array}$ & $\begin{array}{l}.510^{*} \\
(.514)\end{array}$ & $\begin{array}{l}.506^{*} \\
(.517)\end{array}$ & $\begin{array}{l}.620^{*} \\
(.634) \\
\end{array}$ \\
\hline
\end{tabular}

*indicate significant standardized beta coefficients and $R^{2}$ values, ( ) indicate non-adjusted total $R^{2}$ values 